\author{
Jagoda Hernik Spalińska \\ (Instytut Sztuki PAN)
}

\title{
NAJWIĘKSZA LEGENDA TEATRU W Wilnie, CZYLI O ZAMKNIĘCIU SCENY PO POWSTANIU STYCZNIOWYM*
}

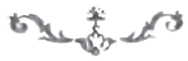

$\mathrm{P}$ RZY OKAZJ I TAK ZWANEGo wskrzeszenia przez Nunę Młodziejowską polskiej sceny w Wilnie w 1906 roku patriotyczne uniesienie kazało uznać wileńskiej opinii publicznej, że wyłączną winę za milczenie polskiego teatru przez ponad czterdzieści lat ponosi zaborca, a polska publiczność została pozbawiona instytucji, która była jej potrzebna do życia jak tlen.

Zazwyczaj zamknięcie sceny w Wilnie w 1864 roku jest wymieniane jednym tchem z wcześniejszymi represjami zaborcy. Łączone z zamknięciem Uniwersytetu, ze zlikwidowaniem Akademii Medyko-Chirurgicznej i Akademii Duchownej, ze zniesieniem Statutu Litewskiego. Zniknięcie polskiego teatru weszło do powstaniowego zestawu martyrologicznego i w istotny sposób wpłynęło później na zdefiniowanie specyficznej tożsamości polskiej sceny. Na pewno wpływ na to miał fakt, że jeden z pierwszych dziejopisów tej sceny, Mieczysław Rulikowski ${ }^{1}$, pisząc o zamilknięciu teatru w Wilnie, stwarza wrażenie, jakby przyczyny tego były polityczne. Nie wymienia dat i powodów, prawdopodobnie dlatego, że książka wyszła w 1907 i nadal podlegała cenzurze. Pozostało jednak wrażenie, iż to „ukaz carski” stał się przyczyną zamknięcia teatru. Wszystko się w tej sekwencji zdarzeń zgadza: powstanie, reperkusje, murawjewszczyzna, w 1864 teatru już nie ma. Choć Rulikowski

* Pierwotna wersja tekstu ukazała się w języku litewskim (Didžiausia Vilniaus teatro legenda, arba apie lenku teatro uždarymas po $1863 \mathrm{~m}$. sukilimo, „Menotyra” 2005, nr 4). Prezentowany tutaj tekst został zmieniony i rozszerzony.

1 M. Rulikowski, Teatr polski na Litwie, 1784-1905, Wilno 1907. 
tego nie napisał, to jeszcze do niedawna historycy teatru przyjmowali ów ukaz carski za pewnik i punkt wyjścia. Zaczęła Helena Romer-Ochenkowska, pisząc expressis verbis: „Na mocy polecenia Murawjewa zawieszono polskie przedstawienia" ${ }^{2}$. Mimo książki Antoniego Millera³ ${ }^{3}$ który podał w roku 1936 to twierdzenie $\mathrm{w}$ wątpliwość, przez następne siedemdziesiąt lat pisze się w opracowaniach teatrologicznych o "przymusowym zamknięciu sceny na 42 lata" 4 , a historycy kultury tego regionu powtarzają to stwierdzenie za historykami teatru 5 .

„Ta agonia zjawiła się nagle” ${ }^{6}$ - pisze Julian Titius, znany wileński lekarz, w swoich niewydanych wspomnieniach. Nie jest to jednak do końca trafna diagnoza. Mogło to tak z pozoru wyglądać, lecz proces umierania polskiej sceny rozpoczyna się co najmniej dwadzieścia lat wcześniej i - jak to choroba przewlekła - ma swoje lepsze i gorsze momenty, chwile realnych szans na uzdrowienie i akty zamierzonej destrukcji lub tylko pomyłek, które razem owocują śmiercią. Upadkiem, który być może był do uniknięcia. Nie na długo, pewnie na dwa-trzy lata, ale teatr polski odszedłby rzeczywiście jako ofiara represji i być może wtedy odrodziłby się wcześniej niż po czterdziestu dwu latach.

Przyjmuje się, że proces upadania polskiej sceny rozpoczął się po powstaniu listopadowym. Przedstawienia polskie nie odbywały się już w tym czasie w pierwszej, pamiętającej Wojciecha Bogusławskiego siedzibie, czyli w Pałacu Oskierczyńskich przy Wileńskiej, lecz w przystosowanym do potrzeb teatralnych przez Kazimierza Morawskiego w 1796 roku pałacu poradziwiłłowskim, też przy Wileńskiej, jakby naprzeciwko. W 1831 roku „zaburzenia krajowe nastąpiły” - jak pisze Kazimierz Skibiński, aktor tej sceny - i „te odebrały zupełną sposobność bawienia publiczności”7. Lecz jak zaznacza Skibiński, w „stagnacji scenicznej” przeszła tylko „cała ta zima i lato całe prawie”. Przybycie do Wilna księcia Nikołaja Dołgorukowa, wojennego generała-gubernatora czterech guberni, a równocześnie wielbiciela „zabaw i pięknych

2 H. Romer-Ochenkowska, Dwudziestopięciolecie wskrzeszonego Teatru Polskiego $w$ Wilnie, Wilno 1932.

3 A. Miller, Teatr polski i muzyka na Litwie jako strażnice kultury Zachodu (1745-1865). Studium z dziejów kultury polskiej, Wilno 1936.

4 A. Kuligowska-Korzeniewska, Przed wskrzeszeniem stałej sceny w Wilnie, w: Wilno teatralne, red. M. Kozłowska, Warszawa 1995, s. 79.

5 Zob. A. Romanowski, Młoda Polska wileńska, Kraków 1999.

6 J. Titius, Daty i wspomnienia dla mojej rodziny. Rozmaitości [1894-1892], Rkps, Biblioteka Litewskiej Akademii Nauk, Wilno, F-8 BF 218.

7 K. Skibiński, Pamiętnik aktora, w: Wspomnienia aktorów (180o-1925), t. 1, oprac. S. Dąbrowski, R. Górski, Warszawa 1963, s. 122. 
sztuk” położyło kres zastojowi. Dołgorukow „otworzył swój dom i obywateli zachęcał, aby z familiami przybywali i zamieszkali w Wilnie. Zaczęło się zaludniać miasto, a następnie teatrowi lepiej zaczynało się powodzić" ${ }^{8}$. W 1833 roku teatr jako swego dyrektora otrzymał policmajstra, pułkownika Skobelcyna, i musiał drukować dwujęzyczne afisze, na widowni zawsze siedział żandarm i wzmagała się cenzura. Policyjny dryl wprowadzony do teatru nie odpowiadał wszystkim aktorom. Skibiński mimo bardzo silnych nacisków, zastraszania i grożenia „kazamatem” nie chciał występować. Jego upór i związane z tym bardzo nieprzyjemne doświadczenia, które opisał w swym pamiętniku, pokazują, jak silna była ta niechęć do produkowania się na scenie pod policyjną dyrekcją. Skibiński był jednak w swym uporze dość wyjątkowy. Nowe porządki w teatrze nie wpłynęły na jego codzienną pracę. Dwujęzyczne afisze zwykle oznajmiały zresztą sztuki grane po polsku.

Za inną przyczynę podupadania sceny (obok częściowej rusyfikacji) jest uważane pojawienie się w 1837 roku w Wilnie niemieckiej opery Wilhelma Schmidkoffa, „który z doborowym towarzystwem i repertuarem nowych oper wystąpił" ". Schmidkoff w istocie osiadł w Wilnie z dobrą operą, pogarszając już i tak niełatwą sytuację. Równocześnie jednak każda udana teatralna impreza, choćby konkurencyjna, na dłuższą metę służy dobrze scenie, bo w ludziach wyrabia się odruch chodzenia do teatru, instynkt włączania tej sztuki do swego życia codziennego, nie tylko od święta. Opera Schmidkoffa była zaś prowadzona na wysokim poziomie, oprócz nowego repertuaru i dobrych wykonawców Schmidkoff „nie żałował na porządną wystawę, tak w dekoracjach, jako też i w kostiumach" ${ }^{10}$. Nic więc dziwnego, że - jak pisał Stanisław Lachowicz: „[...] klasy niższe, nie mówię już o wyższej, tłumnie zasiadały ławki paradyzu i bodaj czy nie ochotniej uczęszczały na operę niż na komedie i dramy" ". Schmidkoff jednak gra nie tylko po niemiecku i nie tylko ze swoimi śpiewakami, bo swe opery „na drugą zimę” - jak pisze Skibiński - daje „łącznie z nami w polskim języku”. Jak również owej „drugiej zimy”, czyli w 1838 roku, angażuje do Wilna Bogumiła Dawisona, wybitnego polskiego artystę dramatycznego, choć dopiero wtedy początkującego ${ }^{12}$.

8 Tamże.

9 Tamże, s. 134

10 Tamże, s. 135.

11 [S. Lachowicz], Wspomnienia i szkice Wilna. IV. Muzyka, „Tygodnik Petersburski” 1840, nr 82, s. 458. Fragment ten jako Korespondencję $z$ Wilna cytuje Małgorzata Stolzman (Nigdy od Ciebie miasto... Dzieje kultury wileńskiej lat międzypowstaniowych (1832-1863), Olsztyn 1987, s. 234).

12 Zob. B. Dawison, Dziennik (1837-1845), w: Wspomnienia aktorów, s. 224-235. 
Jak pisze Małgorzata Stolzman, po egzekucji Szymona Konarskiego młodzież wileńska bojkotowała teatr Schmidkoffa, więc „obrażony antreprener najpierw z miasta wyjechał, potem wrócił i angażując artystów, połączył zespoły, dając na przemian spektakle w obu językach" ${ }^{13}$. Skibiński jednak podaje inną przyczynę wyjazdu niemieckiego dyrektora z Wilna, który „nie postarawszy się o nowe sztuki, zadłużył się aktorom i kupcom i szczęśliwie upatrzywszy porę, przepędziwszy żonę, z drugą potajemnie umknął” ${ }^{14}$. Jak było, tak było, ważne, że Schmidkoff opuszcza Wilno w 1844 roku i znika niebezpieczeństwo germanizacji polskiej sceny. Co dzieje się wtedy? Pod względem repertuarowym na polskiej scenie w latach czterdziestych XIX wieku jest bardzo dobrze, wystawia się dużo sztuk, w tym także, a może nawet przede wszystkim, polskich autorów. Ale gra się też bardzo dużo zagranicznej szmiry, którą publiczność tak lubi. Mimo to są ciągłe problemy z frekwencją. Wtedy właśnie następuje konflikt między artystami polskiej sceny w budynku Macieja Każyńskiego. Niezgoda, być może inspirowana z zewnątrz, między Józefem Surewiczem a Aleksandrem Rezgołem i Stanisławem Nowakowskim, doprowadza do powstania sceny polsko-rosyjskiej. Rezgoł ucieka pod opiekę carskiej administracji i otrzymuje własną scenę w przystosowanym do tego celu ratuszu oraz dotację. Brak finansowej opieki nad polskim zespołem przesądza sprawę. Prymitywne warunki, chłód i brud w budynku Każyńskiego zaczynają dodatkowo działać na niekorzyść grupy Surewicza, bo nie tylko, że utrudniają pracę, ale dają pretekst do tego, by carskie władze zamknęły budynek poradziwiłłowski ze względów bezpieczeństwa. Wymuszona petycja ${ }^{15}$ o rządową opiekę została podpisana przez aktorów z wyjątkiem Emila Derynga, który tak jak Skibiński po mianowaniu Skobelcyna wolał narazić się na niebezpieczeństwo, skonfrontować z gubernatorem Siemionowem i przy wsparciu wielu obywateli uciekać z Wilna, niż grać na rosyjskich warunkach. Reszta zespołu jednak, łącznie z Surewiczem, przyjęła ten los i zaczęła współpracę z grupą Rezgoła w teatrze w ratuszu.

Ale to nie musiał być koniec, ani tego teatru jako budynku, ani polskiej sceny. Jeszcze cały czas nie doszło do spełnienia tego najważniejszego warunku, by teatr przestał istnieć - nie znikła całkowicie publiczność. Najpierw jednak co do budynku:

13 M. Stolzman, dz. cyt., s. 234.

14 K. Skibiński, dz. cyt., s. 136.

15 Okoliczności te opisuje Emil Deryng i wspomina słowa gubernatora Siemionowa: „Toż to wasza petycja, żądacie, żeby was wziąć pod opiekę, żebyście się nie pozabijali”. E. Deryng, Z pamiętników aktora wileńskiego, oprac. J. Pini-Suchodolska, „Pamiętnik Teatralny" 1957, z. 2, s. 274. 
[...] gubernator cywilny chciał kupić ten teatr potrzebujący reperacji niemałych. Oferował właścicielce około 14 tysięcy rubli za gmach z obszernym placem. Każyńska nie zgodziła się i zięć jej wkrótce przerobił budynek na kilka apartamentów, a dół z czasem na aptekę (Mikułowicza) i magazyny. ${ }^{16}$

Budynek stracił swą półwiekową tradycję, bo wdowa po Każyńskim nie chciała go sprzedać. Można by zrozumieć, gdyby nie chciała tego zrobić, bo zależało jej, by chronić polski majątek przed przejęciem przez zaborcę. Jej jednak nie odpowiadała cena, sama zaś nie miała zamiaru budynku odremontować i przywrócić dla oryginalnego przeznaczenia. Teatr zamienił się w miejsce komercyjne. Tu pojawia się do rozważenia problem - czy chronić polskie interesy poprzez zapewnienie ciągłości substancji materialnej, czy niemożliwy do utrzymania obiekt sprzedać zaborcy, który go wyremontuje, przywróci do świetności i pierwotnego przeznaczenia. Rozwiązaniem tego problemu mogło być tylko nawiązanie do tradycji ukształtowanej po wojnach napoleońskich, czyli mecenatu publicznego, zorganizowanego w 1816 roku pod nazwą Dyrekcji Teatralnej, której jednym z zadań było wspieranie finansowe polskiej sceny w Wilnie z funduszów Urzędu Opieki Publicznej ${ }^{17}$. Ta tradycja w tym czasie jednak już była martwa i polska scena nie mogła liczyć na żadne systemowe wsparcie ze strony polskiego ziemiaństwa i miejskiej inteligencji. Kilka lat wcześniej, w 1842 roku Adam Honory Kirkor, obawiając się zniemczenia polskiego teatru, wydał pismo zbiorowe „Radegast”, a do zaproszonych współpracowników, między innymi Józefa Ignacego Kraszewskiego, Józefa Korzeniowskiego, Hipolita Skimborowicza, rozesłał „dramatyczne listy - odezwy o pomoc w podtrzymywaniu ojczystej sceny” ${ }^{18}$. Pismo jednak osiągnęło tylko 108 prenumeratorów i nie było w stanie pomóc finansowo polskiej scenie. Żadna inna inicjatywa tego typu od tamtej pory się nie pojawiła. Tak więc w grudniu 1845 roku odbywa się ostatnie przedstawienie w budynku Każyńskiego, po czym, rok po secesji, grupa Surewicza dołącza do zespołu z ratusza. Jak było wspomniane, aktorom podano do podpisania petycję do gubernatora o wyznaczenie stałej rządowej dyrekcji. Obiecano sto rubli za podpis. Nowy teatr dostał też subwencję rządową (trzy tysiące rubli rocznie) i rządowego dyrektora. Inauguracja nowej sceny odbyła się 14 grudnia. Z jednej strony artystów spotkało upokorzenie, z drugiej próba przypodobania się im, bo podczas inauguracji widzowie wileńscy

J. Titius, dz. cyt., k. 9v.

17 Do Dyrekcji Teatralnej należeli Antoni Chrapowiecki, August Bécu, Leon Borowski i Józef Szumski. 
w swoim polsko-rosyjskim teatrze zobaczyli komedię Aleksandra Fredry Nikt mnie nie zna.

Teatr zaczyna więc podlegać pełnej kontroli, zajmuje budynek narzucony przez władzę, ma prezesa, który przez tę władzę jest mianowany, dostaje wymóg grania po rosyjsku dwa razy w tygodniu. Tego typu układ istniał już w Warszawie i w innych ośrodkach. Tu na chwilę rozważmy, czy dyrekcja rządowa jest czynnikiem sprzyjającym utrzymaniu teatru, czy raczej oznacza początek ostatecznej rusyfikacji sceny. Porównanie do sceny warszawskiej, pozostającej pod dyrekcją rządową, z kolejnymi prezesami - rosyjskimi urzędnikami, wskazuje na to, że dyrekcja rządowa może być dla teatru błogosławieństwem. Instytucja prowadzona za rządowe pieniądze zyskuje stabilność gospodarczą i wchodzi w obszar obiektów chronionych. Dyrekcje warszawskie były raz lepsze, raz gorsze, ale teatr w tym czasie dawał bardzo dużo premier, każdego gatunku, przyjmował wielu artystów, kształcił nowy narybek, bardzo często był remontowany, a nawet inspirował konkursy dramatyczne, na które przysyłano sztuki o tendencji postępowej. Prezesi też często zaczynali utożsamiać się z prowadzoną przez siebie placówką, spolszczali się i bardzo dużo dobrego robili dla polskiej sceny, nigdy zaś nie działali wbrew jej interesowi, między innymi dlatego, że traktowali teatr jako powierzone sobie przedsiębiorstwo, którego upadek uznano by za ich osobistą klęskę i dowód niekompetencji. W Warszawie na przykład dość szybko usuwano prezesów, którzy nie radzili sobie finansowo i narażali teatr na długi.

Można oczywiście w tym miejscu odwołać się do różnicy między traktowaniem przez carat Królestwa Polskiego i Ziem Zabranych. Jednak akurat w wypadku teatru jest to nieuprawnione. Paradoksem bowiem jest, na co zwrócił uwagę Zbigniew Raszewski ${ }^{19}$ właśnie w kontekście sceny wileńskiej, że sytuacja teatru w zaborze rosyjskim była zawsze korzystniejsza niż na przykład w zaborze pruskim, podczas gdy poczynania władz w innych dziedzinach życia były bardziej, a co najmniej tak samo, bezwzględne i okrutne. Wilno też grało repertuar warszawski, który przechodził nie przez cenzurę w Petersburgu, lecz via Warszawa. Dlatego najpoważniejsze kłopoty teatru w Wilnie w latach międzypowstaniowych wynikały z innych źródeł niż polityczne.

W tym kontekście wydaje się, że dyrekcja rządowa była dla teatru w tym mieście warunkiem przetrwania. Aktorzy stracili niezależność, ale uzyskali rodzaj zabezpieczenia materialnego, ratusz został dostosowany do potrzeb teatru na koszt państwa, zespół otrzymał też subwencję. Już w 1850 roku te-

Zob. Z. Raszewski, Krótka historia teatru polskiego, Warszawa 1978, s. 105. 
atr zaczyna przynosić zyski. Kolejni prezesi szanują zarówno personalne, jak i repertuarowe decyzje reżysera polskiej sceny. Jesteśmy więc na etapie, gdy rozkład polskiego teatru jest jeszcze możliwy do powstrzymania, gdy pierwsze kroki na drodze do upadku już nastąpiły, ale jeszcze nie muszą zaistnieć następne.

Warunki sprzyjają. Surewicz, mimo iż początkowo w konflikcie z grupą rozłamową Rezgoła, z czasem jest przez władze wręcz "dobrze widziany” ${ }^{20}$ i de facto przejmuje dyrekcję, podróżuje bez problemu, by szukać dobrego repertuaru. Prezesi się sprawdzają, wśród nich życzliwością dla polskiej sceny i sprawnością administracyjną wyróżnia się Herkulan Abramowicz, który inwestuje w polską operę, dając między innymi sceniczną premierę Hal$k i$ w lutym 1854 roku. W 1859 roku dyrektorem teatru polskiego zostaje inny wybitny reżyser i antreprener Kazimierz Szlagier. Wspaniały, dziś zapomniany, człowiek teatru daje scenie wileńskiej dwie najważniejsze rzeczy - dobry repertuar i dobry zespół. Dyrekcja Szlagiera wzbudziła entuzjazm publiczności, która była zachwycona kolejnym „zmartwychwstaniem” sceny. Repertuar był pełen nie tylko utworów autorów polskich, ale wręcz „tutejszych": Władysława Syrokomli, Antoniego Edwarda Odyńca, Gabrieli Günter-Puzyniny. Piszą oni dramaty wywiedzione z historii Polski i regionu (np. Jerzy Lubomirski, Barbara Radziwiłtówna Odyńca, Muzułmanin na Litwie Puzyniny). Zespół aktorski jest bardzo dobry, wraca nawet do Wilna po ucieczce przed Siemionowem jego najjaśniejsza gwiazda, Emil Deryng. Szlagier jednak nie tylko inwestuje w sprawdzonych aktorów, ale też mimo tak wysoko postawionej poprzeczki, jako rasowy dyrektor wyszukuje jeszcze dla wileńskiej sceny młodzież aktorską, a ona tę poprzeczkę potrafi utrzymać. Przedstawienia rosyjskie są w zasadzie fikcją, ponieważ z braku rosyjskich artystów grają po rosyjsku polscy aktorzy. Rosyjskich przedstawień odbywa się więc niewiele.

Wszystko jest więc na dobrej drodze, by scena wileńska doszła do siebie po wstrząsach i zaczęła pełnić funkcję kulturotwórczą w wyludnionym i wyjałowionym intelektualnie mieście. Przypomnijmy, że Uniwersytetu nie ma już prawie trzy dekady, znikają obie Akademie. Równocześnie jednak zaczyna w tym okresie rosnąć liczba mieszkańców miasta. Między rokiem 1831 a 1870 podniesie się dwukrotnie. Oczywiście gros nowych osiedleńców to Rosjanie, ale nie tylko oni mieszkają w Wilnie. W tym okresie zmienia się społeczny przekrój. Po reformach dochodzi do głosu bogate chłopstwo, które chce swoje dzieci przerzucić do wyższej klasy społecznej - są to poten-

A. Miller, dz. cyt., s. 205. 
cjalni widzowie wileńskiej sceny. To dla ich ogłady i wykształcenia regularnie pojawiają się w Wilnie ich wzbogaceni rodzice, jeśli nie na stałe, to z częstymi wizytami, w których programie wyjście do teatru jest żelazną pozycją. Poza tym, nawet jeśli w Wilnie pojawiło się dużo Rosjan, to scena, o której mówimy, była polsko-rosyjska i rosyjski odbiorca mógł w znacznym stopniu wpłynąć na poprawę finansów, która w efekcie zaowocowałaby także wzmocnieniem sceny jako takiej.

Dlaczego więc tak się nie stało? Co się w tym czasie dzieje z wileńską publicznością? Gdzie jest ten niezbędny element działania teatru: po jednej stronie scena $\mathrm{z}$ aktorami, a po drugiej - widownia. Jedno bez drugiego nie funkcjonuje. Zapał publiczności opadał w Wilnie zazwyczaj równie szybko, jak się budził. W latach sześćdziesiątych XIX wieku można uważać, że była to posłuszna reakcja na apele, które dochodziły z Warszawy, by bojkotować teatr $^{21}$. Dziś jednak wiemy, do jak niewielu ludzi docierała informacja, i jak bardzo nieufnie była przyjmowana patriotyczna propaganda w zrusyfikowanym Wilnie, które w znacznej części uważało cara za swego władcę, a działaczy patriotycznych za rozbijaczy ${ }^{22}$.

I mimo iż teatr zaczął rozwijać się coraz lepiej, zespół konsolidować, repertuar wzbogacać, a zabiegi dyrektora Szlagiera były wręcz nastawione na odbudowanie publiczności ${ }^{23}$, to nagle, jak za dotknięciem czarodziejskiej różdżki, w kwietniu 1860 roku widzów zaczynało być wyraźnie mniej. W 1861 zaś scena zawiesiła swą działalność. Czasowe przerwy w pracach teatrów wystąpiły około marca 1861 roku w nieomal wszystkich miastach Królestwa Polskiego i Ziem Zabranych w związku z dramatycznymi wydarzeniami w Warszawie. Przedstawienia jednak wznawiano. Potem znów teatry nie działały, nawet kilka miesięcy z powodu wprowadzonego stanu wojennego. Zwykle jednak, zwłaszcza w większych ośrodkach, ale nawet w tak niewielkich jak na przykład Płock, teatry wracały do grania. W Wilnie również, nawet podczas tego okresu częściowych i dobrowolnych, solidarnościowych zamknięć, teatr próbował grać. Szlagier zaczyna nowy sezon 1860/1861 Halka, utworem dla polskich patriotów, z Piotrem Zelingerem jako Jontkiem, ale przedstawienia trzeba zawiesić - nikt ich nie chce oglądać. Za czterdzieści lat Zelinger

21 Małgorzata Stolzman (dz. cyt., s. 257) pisze wprost, że w 1862 roku „bojkot przedstawień teatralnych zmusił do ich zawieszenia”.

22 Zob. np. S. Morawski, Kilka lat młodości mojej w Wilnie (1818-1825), Warszawa 1959.

23 Szlagier - według Antoniego Bądzkiewicza - „[...] zwrócił główną uwagę na potrzebę ściślejszego, serdeczniejszego związku pomiędzy tą instytucją artystyczną a ogółem publiczności”. A. Bądzkiewicz, Kazimierz Szlagier, „Kłosy” 1878, nr 655, s. 38 . 
dostanie szarfę z napisem „tęskniącym do rodzimej sceny” ${ }^{24}$. Ale to dopiero za czterdzieści lat. A tymczasem do wybuchu powstania styczniowego zostały jeszcze dwa lata, a teatr już nie ma widza. W działaniu mechanizmu bojkotu widać tu feler - teatry dobrowolnie zamykały się na znak solidarności $\mathrm{z}$ warszawskimi ofiarami, ale gdy już grały, i to polski repertuar, nie było powodu, by publiczność miała nie przychodzić, bo wtedy bojkotowała nie administrację carską, lecz polski zespół. Właśnie poprzez wsparcie polskich przedstawień, a ewentualny bojkot rosyjskich można było zamanifestować swój patriotyczny obowiązek.

W kwietniu 1861 roku artyści odchodzą więc z Wilna, a na koniec próbują jeszcze coś zarobić, zapraszając na tak zwane „pożegnalne” przedstawienia. Grano Zemstę, a zespół zasilił przejeżdżający przez miasto Bogumił Dawison. Ci aktorzy, którzy nigdzie nie znaleźli zatrudnienia, chwytają się różnych zajęć poza teatrem, co bardziej uparci robią benefisy. Organizują imprezy parateatralne jak na przykład „Wieczór instrumentalno-wokalny, na korzyść Artystów Dramatycznych Sceny Wileńskiej, pozbawionych środków do utrzymania się wskutek zawieszenia widowisk teatralnych" ${ }^{25}$ - w sali Klubu Szlacheckiego.

Na sezon 1861/1862, gdy teatry w innych ośrodkach już całkowicie powróciły do grania, teatr wileński znów próbuje się odrodzić tym sprawdzonym sposobem - gwałtownie obniżając poziom. Pojawiają się grupy Arabów i Marokanów, muzyka szkocka i na dzwonkach. Mimo wszystko teatr zamierał. W 1862 roku Dawison, znów zapraszany do wsparcia kasy swoim występem pisze do Zelingera: „Powiadają, że publiczność żadnym sposobem do teatru zwabić się nie da. A przed pustym, albo nawet niepełnym teatrem grać nie myślę. Mówią, że czasem rozkupują bilety, ale nie chodzą do teatru. I tego także ryzykować nie mogę" ${ }^{26}$. Walka o publiczność została bowiem ostatecznie przegrana. Skalę upokorzenia pokazuje historia o generale-gubernatorze Władimirze Nazimowie, który przekazał nestorowi polskiego aktorstwa Janowi Chełmikowskiemu sto rubli, gdy aktor popadł w ubóstwo, do którego doprowadziło go „zamknięcie przez dwa lata dobrowolne teatru” ${ }^{27}$, i próbował na licytacji sprzedać swojego kanarka.

Po powstaniu styczniowym, w sezonie 1863/1864 Zelinger organizuje

24 Album pamiątkowy Piotra Zelingera, „Dział rzadkiej książki”, Archiwum Biblioteki Litewskiej Akademii Nauk, Wilno, F.151, sygn. 919.

25 Tamże.

26 List B. Dawisona do P. Zelingera, Petersburg, 5/17 maja 1862, w: Album pamiątkowy Piotra Zelingera.

27 J. Titius, dz. cyt., k. 7ov. 
wznowienia przedstawień, teatr znów zaczyna działać. Ciekawie w tym kontekście rysuje się rola Murawjewa:

[...] w 1863 i 1864 r. Jen. Gub. Murawjew rozkazywał pozostałym w Wilnie polskim aktorom grywanie $\mathrm{w}$ dni galowe po rusku i po polsku (jak przedtem), ale ponieważ w owych krwawych czasach żaden Polak tam, w teatrze, nie pokazał się - kazał wysłać w jesieni 1864 ruskich aktorów do Petersburga. ${ }^{28}$

Kontynuowano jeszcze grę po polsku w 1864, ale sporadycznie. Wypada więc uznać, że teatr umiera w Wilnie w roku 1860, potem tylko dogorywa, dając przedstawienia jeszcze pod koniec 1864 .

Co się stało? Oto spełnił się ten jedyny skuteczny, poza zakazem administracyjnym, powód, by teatr przestał istnieć - publiczność przestała chodzić do teatru i dobiła swoją absencją walczącą o przetrwanie scenę.

Zastanówmy się więc, dlaczego publiczność wileńska na długo przed 1864 rokiem przestała odwiedzać swój teatr? Mówi się, że przestała chodzić do teatru, protestując przeciwko restrykcjom. Jednak restrykcje po powstaniu listopadowym były bardziej okrutne, ale to ludzi do teatru nie zniechęciło. W roku 1839 Wilno przeżyło szok po publicznej egzekucji Konarskiego, która nawet według słów carskiego urzędnika „dokonała silnego wstrząsu umysłów mieszkańców, wzbudziła nie strach, nie przerażenie, lecz [...] wzburzyła umysły młodzieży, wzbudziła w nich gorące uczucia patriotyzmu i stworzyła podstawę dla przestępczych zamysłów licznych kontynuatorów jego sprawy" ${ }^{29}$, co zaowocowało chwilowym bojkotem, szybko jednak sprawy wróciły do normy. W 1858 roku podczas przedstawienia społeczeństwo wileńskie ofiarowało carowi Aleksandrowi II Album; akt ten „został potępiony w Warszawie i Paryżu przez młode głowy" ${ }^{30}$. W 1860 roku, w pierwszych dniach października, car znów pojawił się w Wilnie. Nadeszły listy z Warszawy, zabraniające udziału w balu w Zakrecie. Jednak nikt nie posłuchał mimo niedawnego potępienia za album. A równocześnie w 1861 roku „za przykładem i zaleceniem Warszawy, [...] po pierwszej pamiętnej tam demonstracji, zaprzestano uczęszczać do teatru" ${ }^{31}$.

Dlaczego po tej akcji bojkotowej Warszawa bardzo szybko do teatru wróciła, a wileński widz od teatru odwrócił się na stałe? Dziwne też wydaje się, że litewscy ziemianie słuchają młodych głów z Paryża i z Warszawy. I dla-

28 Tamże.

29 Pułkownik Łunaczarski, członek komisji śledczej w raporcie do Petersburga, cyt. za: M. Stolzman, dz. cyt., s. 19.

30 J. Titius, dz. cyt., k. 15.

31 Tamże. 
czego miano słuchać ich akurat w sprawie teatru? Tym bardziej że jeszcze pamiętano Warszawę po powstaniu listopadowym. Jak wspominał Titius: „Nadspodziewanie znalazłem ją ożywioną i bawiącą się. Teatry przepełnione, ledwie mogliśmy przez protekcję otrzymać bilety na przedstawienie" ${ }^{32}$. Dlaczego więc właśnie Warszawa miałaby mówić Wilnu, kiedy chodzić do teatru?

W Wilnie, gdzie rusyfikacja przebiegała na szerszą skalę niż w Królestwie Polskim i ochrona każdego przybytku polskości odwlekała moment ostatecznego zrusyfikowania pokolenia zrodzonego już w niewoli, raczej nie bojkot, a popieranie polskiej sceny, dopóki tymi restrykcjami nie została objęta, miało szanse, by zostać uznane za akt patriotyzmu. Nie chodzić do mówiącego po polsku teatru to tak, jakby nie kupować w carskim Wilnie polskiej książki. Trudno sobie wyobrazić, by przyzwyczajeni do rosyjskich rządów w mieście i guberni wilnianie bojkotowali polskie przedstawienia, bo ich wrażliwość moralna nie pozwalała na chodzenie do budynku administrowanego przez carat.

Może więc wprowadzenie języka rosyjskiego na dwa przedstawienia w tygodniu stało się nie do zniesienia dla wileńskiej publiczności, było postrzegane jako akt rusyfikacyjny, na który odpowiedź może brzmieć tylko non possumus? Język ten jednak został wprowadzony dwadzieścia lat wcześniej. Poza tym była to jednak dość naturalna cena za dotację.

Może więc było w Wilnie za mało ludzi, za mało inteligencji czy mieszczaństwa, by teatr miał dość widzów?

Polistopadowe represje dotknęły cały kraj - w Wilnie zamknięto uniwersytet już wtedy i kontyngent widzów drastycznie się zmniejsza, ale od tego czasu teatr funkcjonował jeszcze trzydzieści lat. Rolę uczelni przejęła Akademia Medyko-Chirurgiczna i Duchowna. Przenosi się jednak do Petersburga w 1842 roku. Na pewno wpłynęło to znowu na zmniejszenie się liczby widzów, ale stało się to ponownie na dwadzieścia lat przed upadkiem sceny.

Sprawdźmy, jak wobec tego braku odbiorcy radziły sobie inne dziedziny kultury, jak książka, jak prasa? Dzieje wileńskich wydawców i księgarzy pokazują, że upadali i się odradzali, dostawali pozwolenia i je tracili na nowo. Do 1865 roku, gdy gubernator Konstantin Kaufman wydał całkowity zakaz polskich druków, polska książka i prasa radziły sobie lepiej niż teatr. Mimo braku tego samego odbiorcy - inteligencji i studentów. Ale również potem wydawcy i księgarze skuteczniej walczyli o ponowne zaistnienie. Minęły tylko trzy lata od zarządzenia gubernatora cywilnego Kaufmana i polskie 
książki znów zaczęły drukować się w Wilnie. Eliza Orzeszkowa zaś, w 1881 roku, metodą faktów dokonanych doprowadziła do uchylenia zakazującego druku polskich kalendarzy okólnika Murawjewa z 1864 roku ${ }^{33}$.

Kim we wczesnych latach sześćdziesiątych XIX wieku byli potencjalni odbiorcy polskiej sceny w Wilnie? Jest to okres kształtowania się wczesnego kapitalizmu, przenoszenia kultury z dworu do miasta - w Wilnie stosunkowo słabe ze względu na małą urbanizację. Jak pisze Małgorzata Stolzman: „Na kształt intelektualny miasta mieli wpływ ludzie mieszkający na wsi, systematycznie zaglądający do Wilna dla odwiedzenia znajomych, księgarń i wydawców" ${ }^{34}$. Po powstaniu listopadowym Wilno ma pięćdziesiąt tysięcy mieszkańców, połowa Żydzi i Rosjanie, dwadzieścia pięć tysięcy Polaków. Jak wiadomo, wywózki i inne reperkusje popowstaniowe doprowadziły do istotnego wyludnienia miasta. Jednak już w 1879 roku w Wilnie mieszka dziewięćdziesiąt pięć tysięcy ludzi. Kim byli ci nowi mieszkańcy? Gdy chłopi zaczęli kształcić swoje dzieci, opuszczały one wsie i przenosiły się między innymi do Wilna. Czy mogły zająć szeregi krzeseł na widowni polskiej sceny? Raczej nie, ruchy chłopskie z lat czterdziestych miały charakter społeczny, ale też antypolski, były skierowane głównie przeciw szlachcie. Dlatego chłopi wcale nie chcieli, by ich dzieci poznawały kulturę polską, woleli, by wchodziły w krąg rosyjski. Podobnie ludność żydowska w tym okresie, jeśli odchodziła od swojej hermetycznej kultury, raczej się rusyfikowała niż polonizowała. Polska scena mogła więc liczyć głównie tylko na swojego tradycyjnego odbiorcę, czyli miejską inteligencję polską i ziemiaństwo zamieszkujące okolicę. Ono właśnie, mimo wszystkich działań caratu pozostawało stosunkowo zamożne i ono jedynie mogło zmienić sytuację polskiej sceny.

W działaniach kulturotwórczych i społecznikowskich w tym okresie rola ziemiaństwa wzrasta, tym bardziej że zmienia się wtedy forma mecenatu. Z centralnego - jak w czasie, gdy działał w Wilnie Uniwersytet - na społeczny, wychodzący ze sztywnej struktury. W Wilnie był to tym bardziej naturalny proces, że po zniknięciu Uniwersytetu, funkcję głównego animatora kultury polskiej, wobec braku rozwiniętej kultury miejskiej, przejęli ziemianie, samozwańczo niejako i na własną rękę. Ten to mecenat społeczny, bez choćby minimalnej kontroli intelektualnej, jaką wprowadzał swymi działaniami wcześniej choćby Adam Kirkor czy w obszarze samej muzyki Stanisław Moniuszko, miał pewne negatywne uwarunkowania. Zachowawcze

Por. A. Romanowski, Między „mrozem” a „odwilża”. Polski ruch księgarski i wydawniczy na Litwie i Białorusi w latach 1864-189o, w: Życie literackie i literatura $w$ Wilnie XIX-XX wieku, red. T. Bujnicki, A. Romanowski, Kraków 200o, s. 77.

M. Stolzman, dz. cyt., s. 10. 
kręgi ziemiańskie miały swoją bardzo szczególną specyfikę. Jest to mieszanina $\mathrm{z}$ jednej strony silnego patriotyzmu lokalnego $\mathrm{z}$ równoczesną pogardą dla tego, co swojskie. Ci, w dużym stopniu rozbestwieni Paryżem arystokraci i snobujący się na Włochy ziemianie, traktowali polską scenę jako miejsce, które można wspierać, ale wstyd tam chodzić, jako sztukę prowincjonalną, która nie ma człowiekowi z ich sfery nic do zaoferowania. Dlatego protekcjonalnie wykupywali bilety, ale do teatru nie szli, nie chcąc się męczyć, słuchając niewyrobionych - w stosunku do francuskich, włoskich i niemieckich - śpiewaków. Woleli w tym czasie snobować się na teatromanię podczas amatorskich przedstawień na salonach u Doroty Łopacińskiej ${ }^{35}$. Ta atmosfera musiała też oddziaływać na innych widzów, którzy dopiero aspirowali do wyższych sfer. Podobny los spotkał wcześniej antrepryzę Bogusławskiego we Lwowie (1796-1798) i Kraszewskiego w Żytomierzu. Tymczasem można sobie wyobrazić taki korzystny układ, że polska scena w Wilnie jest - wzorem na przykład sceny krakowskiej - z jednej strony subwencjonowana przez administrację, ale równocześnie pod stałą opieką jednego z bogatszych i wybitniejszych ziemian albo nawet Radziwiłłów czy Tyszkiewiczów. Wtedy zarówno jej finansowa kondycja byłaby lepsza, jak również widzowie nie wstydziliby się przychodzić na książęcą imprezę.

Nie pastwmy się jednak dłużej nad wileńskim i podwileńskim widzem. W dziejach teatru bywają takie okresy, że ludzie nagle do teatru chodzić przestają. To okresy zmian, przełomów (w Polsce współczesnej takie zjawisko nastąpiło ostatnio na początku lat dziewięćdziesiątych XX wieku). „Widzi się pewne zobojętnienie publiczności na sprawy teatralne" ${ }^{36}$ - pisał Mieczysław Rulikowski o latach sześćdziesiątych XIX wieku. Polska publiczność odeszła wtedy nie tylko z wileńskiego ratusza. Również w innych zaborach można zaobserwować odpływ widzów z teatrów. W roku 1862 w Czerniowcach pada polska scena. Także z powodu słabej frekwencji, mimo dobrej dyrekcji Bolesława Leszczyńskiego. Nawet niemiecki dziennik „Bukowina” w 1864 upomina się o niezaniedbywanie polskiej sceny przez polską publiczność. Przypomina to sprawę z kanarkiem Chełmikowskiego. I tak jak w Wilnie w wyniku tych tendencji odpływowych następuje obniżenie wartości repertuaru, tak w teatrze w Czerniowcach pojawiają się sentymentalne lub sensacyjne sztuki francuskie, które mają przyciągnąć publiczność, ale scena i tak upada. To samo dzieje się nawet w większych ośrodkach, choć na

35 Łopacińska prowadziła w tym okresie w Wilnie i w Kojranach przez dwadzieścia pięć lat scenę amatorską, na której m.in. wystawiono wszystkie utwory Aleksandra hr. Fredry.

M. Rulikowski, dz. cyt., s. 79. 
mniejszą skalę. W tym samym 1864 roku publiczność krakowska nie popiera swojego teatru tak, jak powinna, a grają przecież Kraszewskiego, Syrokomlę, Bogusławskiego. Nie wynika to więc z niezgody na brak polskiego repertuaru.

Czyli nic szczególnego w Wilnie się nie dzieje. Nie można jednak mówić, że przyczyna kryzysu w teatrze nie leżała w widzach. Paradoksem bowiem jest, że Kazimierz Szlagier w Wilnie to - po rosyjskich prezesach - wreszcie Polak, scena zamarła więc, mając jednego z najlepszych w swej historii dyrektorów.

Dlaczego więc polska publiczność, mając możliwość wsparcia swej sceny, zamanifestowania swej polskości, odrębności poprzez gremialne odwiedzanie polskiego teatru, wolała w tym czasie zostać w domu? Poza tymi czynnikami, które już zostały tu wymienione, czyli zmniejszenie liczby widzów, pewna konfuzja co do tego, jaki czyn jest patriotyczny, a jaki nie, czy wreszcie zwykły brak zainteresowania dla teatru i propagowany przez polskie ziemiaństwo rodzaj pogardy dla swojskiej muzy, dochodzi jeszcze jeden czynnik.

Wspomnijmy znów wdowę po Każyńskim, która wolała złamać półwieczną tradycję budynku i teatr zamienić na zajazd, niż stracić finansowo. Przypomnijmy też generała-gubernatora Fiodora Mirkowicza, tak zwanego „rusyfikatora z zamiłowania”, który doprowadził do zniesienia Statutu Litewskiego i zamknięcia obu akademii, który nasilił rusyfikację szkolnictwa i wprowadził przepisy inwentarzowe (które doprowadziły do pozbawienia szlachty polskiej ziemi i zastąpienia jej rosyjskimi kolonistami), itd., itd., ale teatru polskiego nie zamknął. O czym świadczą te dwa fakty razem zestawione? O tym, że teatr mało kto wówczas uważał za czynnik kulturowy, edukacyjny czy w końcu polonizacyjny. Sam Mirkowicz odnośnie do teatrów wędrownych zaczął mieć tego rodzaju przeczucie ${ }^{37}$, lecz raczej widział to w kategoriach politycznych i tym bardziej był zdziwiony, bo teatr to przecież rozrywka i to nie ta najbardziej wyszukana. Dziś teatr uważamy za sztukę wyższą i jako taki obarczamy misją, zarówno tą kulturotwórczą, jak i narodową. Połowa wieku XIX to jednak dopiero początek tego typu myślenia. Jego start możemy dość precyzyjnie określić - to prapremiera Krakowiaków i górali w Warszawie 1 marca 1794. Teatr zaczął od tego momentu powoli

Zbigniew Jędrychowski cytuje pismo gubernatora wojennego Fiodora Mirkowicza do ministra spraw wewnętrznych Rosji. Mirkowicz pisze o „[...] nieprawomyślności dyrektorów wędrownych zespołów aktorów, którzy pozwalali sobie niekiedy dawać przedstawienia całkiem niestosowne”. Zob. Z. Jędrychowski, Antrepryza Jana Chełmikowskiego w Mińsku Litewskim, w: Wilno teatralne, s. 70. 
wchodzić do świadomości zarówno widzów, jak i ludzi teatr tworzących, jako nośnik treści patriotycznych. Nawet jednak, jeśli uznać, że poszczególne przedstawienia od tego czasu mogły być uważane za manifestacje polityczne, to idea teatru jako instytucji państwowotwórczej, wartej wspomagania na co dzień, długo przedzierała się do powszechnego odczucia. W 1853 roku Adam Honory Kirkor pisał do Eustachego Tyszkiewicza: „[... ] teatr w kwestii narodowej ważną stanowi misję" ${ }^{38}$. Ta myśl w miarę równocześnie zaświtała w głowie intelektualisty Kirkora i satrapy Mirkowicza. Opinią ogółu stanie się jednak dopiero za pięćdziesiąt lat, w roku 1906. Ale nawet wtedy, gdy teatr stał się przede wszystkim czynnikiem kulturotwórczym, a nie zabawowym, publiczność nadal dokonywała swych wyborów niezależnie od publicznych zobowiązań. Misyjny charakter sztuki teatru nawet na początku XX wieku nie podniósł jego popularności. Każą tak uważać sytuacje analogiczne do tej z XIX wieku, które zdarzyły się na tym samym terenie, w innych warunkach.

Artykuł ten zaczął się od wspomnienia egzaltacji teatralno-patriotycznej, która towarzyszyła Nunie Młodziejowskiej przy tak zwanym wskrzeszaniu polskiej sceny w 1906 roku. Czy tego pięknego dnia wskrzeszenia młoda dyrektorka, która dla swej sceny przygotowała ambitny repertuar i poświęciła własne finanse, spodziewała się, stojąc na scenie pod deszczem kwiatów, że ta sama publiczność odmówi jej imprezie prawa do istnienia już po czterech sezonach? Czy Juliusz Osterwa przypuszczał, że jego teatr, w najgłębszym znaczeniu tego słowa misyjny, przyjęty w 1925 roku w Wilnie przez publiczność wręcz ekstatycznie, będzie wkrótce omijany i lekceważony, mimo iż nikt widzom nie zabraniał chodzić do tej jakże państwowotwórczej placówki? I nawet jeśli uznamy, że teatr w pierwszej połowie XX wieku zyskał konkurencję w postaci nowych mediów, jak radio i kino, to jednak możemy stwierdzić, że to absencji w teatrze wileńskim do końca nie tłumaczy. Dlatego musimy przyjąć, że w latach pięćdziesiątych i sześćdziesiątych XIX stulecia odpływu publiczności od teatru w Wilnie nie powodują czynniki patriotyczne; nawet jeśli je traktować, jak chciał Jerzy Got, jako „fałszywą postawę patriotycznych Polaków” ${ }^{39}$, to tę „fałszywą" postawę przyjęto, by zamaskować zwykły brak zainteresowania.

Legenda polskiej sceny w Wilnie jako wyłącznej ofiary caratu była silna, a w jej trwaniu pomogli ludzie, którzy doskonale wiedzieli, w jakich okolicznościach polski teatr z Wilna znikał. O tyle łatwo było ją podtrzymać, że

38 List A.H. Kirkora do hr. E. Tyszkiewicza, cyt. za: S. Kirkor, Przeszłość umiera dwa razy. Powieść prawdziwa, Kraków 1978, s. 34.

39 J. Got, Prowincjonalna Modrzejewska, „Pamiętnik Teatralny” 1954, z. 4. 
już niedługo nadeszły czasy Kaufmanna i polska scena pewnie i tak zostałaby zamknięta około 1866 roku. Ale wtedy może by się odrodziła na początku lat siedemdziesiątych, tak jak polska książka. Fakt, że to nie nastąpiło, jeszcze raz potwierdza, że nie było dość determinacji, by o scenę zawalczyć. Pisał Titius: „Zamknięcie polskiej sceny stało się faktem dokonanym bez specjalnego na to rozkazu. [...] I teatr polski jakby dobrowolnie istnieć przestał" ${ }^{40}$. Dobrowolnie? Nie. Likwidacji tego przejawu polskości na pewno w ostatnich dekadach XIX wieku chciała administracja carska, lecz niewiele w tej sprawie musiała zrobić, bo swym zaniechaniem wyręczyła ją w tym publiczność wileńska.

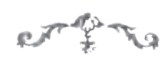

\section{A B S T R A C T}

The Greatest Legend of the Vilnius Theatre: On Closure of Theatres After the January Uprising

The article discusses the causes of the 42 year closure of the Polish theatres in Vilnius, between the years 1864 and 1906. According to the general opinion and historical knowledge, they were closed by the Russian authorities as a part of post-Uprising restrictions. Closer research shows, that the reasons behind it were more complex, and although the Russian policies where not facilitating the development of Polish theatre and made the conditions hard to bear for actors and audiences alike, the immediate and ultimate reason for the disappearance of Polish theatre from Vilnius was the theatergoers' apathy.

KEYWORDS

history of Polish theatre, history of Vilnius, January Uprising, Julian Titius, Nuna Młodziejowska

40 J. Titius, dz. cyt., k. 1v. 